\title{
The concept of good faith in international investment disputes - the arbitrator's dilemma
}

\author{
by A F M Maniruzzaman
}

$\mathrm{T}$ he concept of good faith has been a subject of perennial controversy since it was derived from the Roman legal equivalent "bonas fides." Juristic views on and the legal conceptualization of the idea of good faith may often vary across the cultural divides and legal traditions. At a higher level of abstraction there may be a semblance of understanding that it is a moral principle and is reflective of all good senses such as honesty, good conscience, fairness, equity, reasonableness, equitable dealing or fair dealing, etc, but its application may cause the divergence of opinions. This has caused some uncertainty about the nature of the concept itself and the consequent unpredictability of the outcome of its application.

When focused on the content of good faith, the courts in different countries as well as academic commentators seem to be often baffled. Nor in the sources of the lex mercatoria such as the UNIDROIT Principles of International Commercial Contracts, the Principles of European Contract Law, and the United Nations Convention on Contracts for the International Sale of Goods (CISG or the Vienna Sales Convention) can one find a clear definition of the content of the notion of good faith. In order to rationalise good faith jurists have proffered various legal theories ranging from efficiency arguments to formal entitlements in the spirit of solidarity to its conceptualisation in a more specific sense as "a true behavioural standard." This dilemma pervades in international law in general and in the emerging case law of international investment law in particular. Therefore, it proves the international arbitrator's task in an investment dispute all the more difficult as in any other field when it comes to define the concept and to render any decision on the basis of it.

It thus merits a fresh look at the concept of good faith in order to understand its scope and function in a contractual relationship which is the focus of this article. In order to apply the concept to a particular context, good faith could be considered a functional or objective one in the sense of a framework of relationship between the parties to a contract and cooperation being its underlying current. In this respect good faith is a framework concept based on cooperation as its philosophical foundation. In international business-contracting the consideration of mutual interests of the contracting parties in the spirit of cooperative dealing seems to get favour in some quarters as a manifestation of modern trend of collectivism as opposed to the nineteenth century legacy of individualism. Farnsworth, however, observes:

\section{"Good faith performance has always required the cooperation of one party where it was necessary in order that the other might secure the expected benefits of the contract. And the standard for determining what cooperation was required has always been an objective standard, based on the decency, fairness or reasonableness of the community and not on the individual's own beliefs as to what might be decent, fair or reasonable. Both common sense and tradition dictate an objective standard for good faith performance" (E Allan Farnsworth, Good Faith Performance and Commercial Reasonableness Under the Uniform Commercial Code, $30 \mathrm{U}$ CHI L REV 666 (1963)).}

It needs to be stressed that cooperation should not be understood in the sense of familial relationship such as motherly love or brotherly affections, but must be confined to the contractual relationship, hence the notion of good faith as a framework concept, ie fidelity to the bargain, as mentioned earlier. As far as the content of good faith is concerned the focus has to be specific in a particular context concerned in the contractual framework to see if the parties have acted in the spirit of cooperation, ie good faith cooperation (see L CarvajalArenas, 'Good Faith in the Lex Mercatoria: An Analysis of Arbitral Practice and Major Western Legal Systems (PhD Thesis, University of Portsmouth, 2011)). In numerous 
domestic court decisions (eg United Group Rail Services Limited v Rail Corporation New South Wales [2009] NSWCA 177: $\quad$ http://www.austlii.edu.au/au/cases/nsw/ NSWCA/2009/177.html and see also relevant cases mentioned therein)) and in international judicial (eg the North Sea Continental Shelf cases (ICJ): http://www.icjcij.org/docket/files/52/5561.pdf), and arbitral decisions (eg Wintershall v Qatar (1990) 15 Yb Comm Arb'n 30, Mechema Ltd (England) v SA Mines, Minérais et Métaux (MMM) (Belgium) (1982) 7 Yb Comm Arb'n 77) there seems to be a tendency to give weight to the context in which the concept is to be meant. Article 31 (1) of the Vienna Convention on the Law of Treaties also points out the importance of the context of the terms of the treaty while interpreting it in good faith. Therefore, the content of the concept of good faith is more of a contextual nature than the concept itself understood in the abstract sense.

The International Court of Justice observed: “(t)he principle of good faith is 'one of the basic principles governing the creation and performance of legal obligations'; it is not in itself a source of obligation where none would otherwise exist" (ICJ, Border and Transborder Armed Actions Case (Nicaragua v Honduras), Jurisdiction and Admissibility, judgment December 20, 1988, ICJ Rep 69, at 105 (1988)).

One may thus wonder if good faith can be understood in two senses, viz, "macro good faith" and "micro good faith." In respect of the former the abstract notion of good faith in the sense of honesty, fairness, reasonableness signifying its subjectivity may be meant, ie "macro good faith" - a horizontal approach, a layer of idea which is generic (ie an idea at a higher level of abstraction) and may not be understood the same in different factual patterns as it will depend on its application to them. Thus, from the notional point of view good faith in the macro sense is considered to act as a major interpretative principle. While, on the other hand, it should be appreciated that what appears to be good faith in one context may not appear the same in another context with a different pattern of facts, situations or surrounding circumstances. Thus, the notion of good faith focusing on the particular context concerned - ie the vertical approach - may be understood as "micro good faith" which brings with it the sense of objectivity rather than subjectivity understood in the horizontal sense, ie "macro good faith."

It should be appreciated that the pacta sunt servanda principle, being the foundation of all contracts, is the manifestation of "macro good faith." But "micro good faith" being applied in specific factual contexts may limit the application of the pacta sunt servanda principle in order to conform to it, even in changed circumstances that affect the contract (see A F M Maniruzzaman, "State Contracts with Aliens - The Question of Unilateral Change by the State in Contemporary International Law" (1992) 9 J Int'l Arb 141; Detlev Vagts, "Essays in Honor of Oscar Schachter, Rebus Revisited. Changed Circumstances in

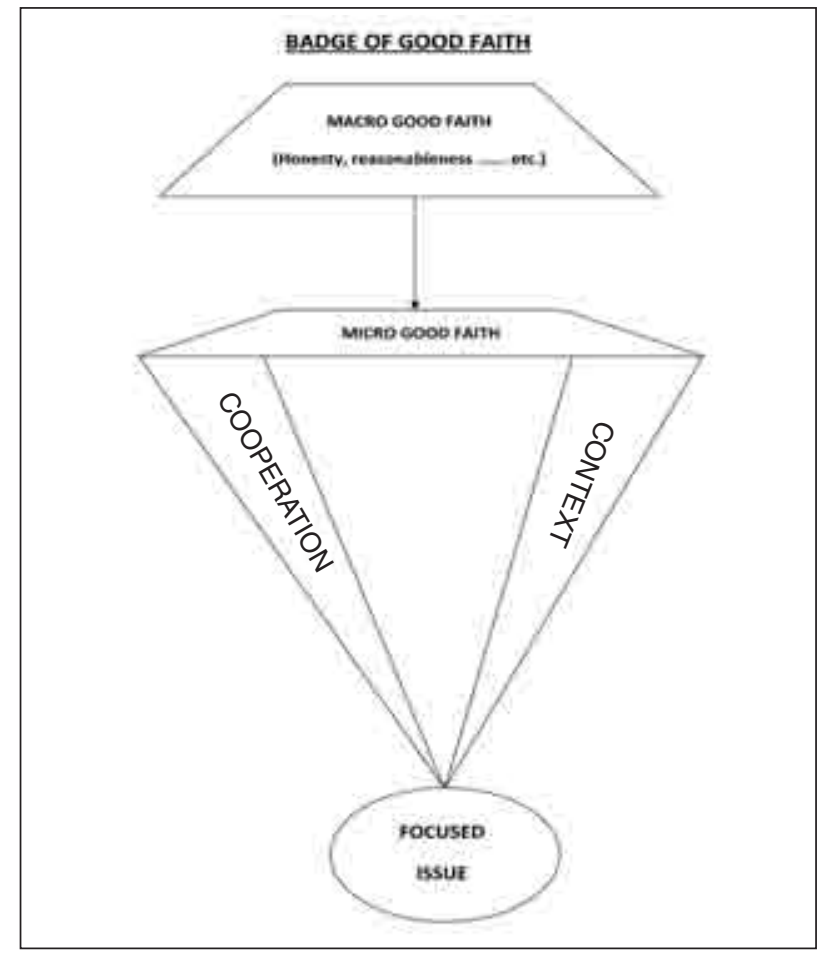

Treaty Law," 43 Columbia J Trans L (2005), 459). Therefore, the pacta sunt servanda principle in a contractual relationship may not be applied as an incantation or in the abstract sense, rather it should be assessed in terms of "micro good faith."

The above conceptual paradigm may be termed as the "badge of good faith" and can be shown diagrammatically as follows. In the diagram (see above) "macro good faith" represents as a concept at a higher level of abstraction which sits horizontally and underneath it goes down "micro good faith" as a functional or objective concept which is particularly pointed with its two arms "cooperation" as the underlying current and "context" as the target beam - to a focused issue in respect of which good faith is questioned. Thus, depending on whether good faith exists or not in respect of a particular issue, the "badge of good faith" can operate as a thinking process and can determine itself the worthy place where it belongs (ie to certify the existence of good faith).

In international investment law, substantive standards of treatment (investment treaty provisions) such as fair and equitable treatment, full protection and security, protection of legitimate expectation, transparency, nondiscrimination, national treatment and most favoured national treatment, are considered fundamentally based on good faith, or manifestations or corollaries of good faith, but their content depends on the specific contexts in which they are applied. Here comes the crunch point when one asks: even if a state literally complies with the foregoing standards in respective cases, will it be always considered to have acted in good faith in its relationship to the other contracting party? Inversely, if a state acts in good faith to comply with its non-investment international treaty obligations relating to human rights, the environment or 
climate change that may interfere with investors' rights, will it be implicated in bad faith vis-à-vis the foreign investors? It is difficult to give any straightforward answers to these questions. The answers, however, may be found specifically in the contexts in which the notion of good faith is to be examined. In investment arbitration jurisprudence such a contextual extrapolation seems to be increasingly endorsed rather than the simple meaning attributed to a standard of treatment: see for example the S D Myers (S D Myers, Inc v Government of Canada (2000), partial award: http://italaw.com/documents/ SDMeyers1stPartialAward.pdf;); Mondev (Mondev Int'l Ltd $v$ USA: http://italaw.com/documents/Mondev-Final.pdf0; $A D F$ (ADF Group Inc and USA (2003): http://italaw.com/ documents/ADF-award_000.pdf); Loewen (The Loewen Group, Inc and Raymond L Loewen V USA (2003): http://italaw.com/documents/Loewen-Award-2.pdf); and Waste Management ( Waste Management, Inc v United Mexican States: http://italaw.com/documents/laudo ingles.pdf).

Often, in order to reflect good-faith cooperation in an investment contract situation the aforementioned standards of treatment for foreign investors may have to be weighed against the state party's competing public interests, such as the protection of the environment, the promotion and protection of human rights and the securing of the economic development of the host country. There seems to be a growing support for such a stance amongst various stakeholders such as host countries, NGOs, international organisations (the World Bank and the IMF, etc.) and others, though this aspect of international investment law is still in the early stage of development.

The scope and content of the standards of treatment for foreign investors may differ from contexts to contexts entailing the understanding of good faith in the micro sense. As the comments to section 205 of the UCC also states, in a different domain of law though, that " $[\mathrm{t}] \mathrm{he}$ phrase 'good faith' is used in a variety of contexts, and its meaning varies somewhat with the context." To get a result then it would be advisable to look at the notion of "micro good faith" - a context-based one with the objectivity that underscores the framework of relationship, cooperation being its philosophical foundation. Good faith in a particular situation should thus be understood not as an abstract concept but as a functional or objective one, i.e. in the micro sense, covering all stages of a contract. This micro approach to good faith may help us solve major problems or disputes, as the adage goes: "good things come in small packages."

If the above conceptual clarification of good faith bears some value, its relevance will not only be in international investment law but also in international law (in general) and other branches of international law and, above all, in domestic laws.

- An earlier version of this article has been published in Kluwer Abitration Blog.

Professor A F M Maniruzzaman, PhD (Cambridge), FRSA

The author is Chair in International Law and International Business Law \& Director of Research and Postgraduate Research Degrees, School of Law, University of Portsmouth. He is also an Honorary Fellow (Professorial) at the Centre for Energy, Petroleum, and Mineral Law and Policy (CEPMLP), University of Dundee, Scotland. 